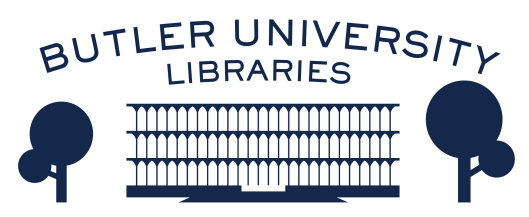

Journal of Hindu-Christian Studies

Volume 26

Article 21

November 2013

\title{
Book Review: The Language of Disenchantment: Protestant Literalism and Colonial Discourse in British India
}

Roselle M. Gonsalves

University of Calgary

Follow this and additional works at: https://digitalcommons.butler.edu/jhcs

Part of the Religion Commons

\section{Recommended Citation}

Gonsalves, Roselle M. (2013) "Book Review: The Language of Disenchantment: Protestant Literalism and Colonial Discourse in British India," Journal of Hindu-Christian Studies: Vol. 26, Article 21.

Available at: https://doi.org/10.7825/2164-6279.1560

The Journal of Hindu-Christian Studies is a publication of the Society for Hindu-Christian Studies. The digital version is made available by Digital Commons @ Butler University. For questions about the Journal or the Society, please contact cbauman@butler.edu. For more information about Digital Commons @ Butler University, please contact digitalscholarship@butler.edu. 
other side - are both called 'Word of God.' Nevertheless, over and above the startling apparent similitude between the two Sacred Scriptures, our study has enabled us to discern the profound dissimilarities between the Christian and the Hindu conceptions of their own Sacred Scriptures as 'Word of God.' A better knowledge of the nature of the Veda as Word of God will help us - so we hope - to better appreciate the Veda as Sacred Scripture of the Hindus." (My translation)

The book is extremely informative, balanced in its approach and should be required reading for all who are interested in Hindu-Christian dialogue.

Klaus Klostermaier, FRSC

University of Manitoba

\section{The Language of Disenchantment: Protestant Literalism and Colonial Discourse in British India. Robert A. Yelle. New York: Oxford University Press, 2013. xxii +298 pages.}

TO expose the notion of disenchantment as myth is to draw into focus the questionable nature of modern secularity, thus reestablishing the 'truths' of history and the genealogy between Christianity and modernity. Robert A. Yelle, assistant professor in the Department of History and the Helen Hardin Honors Program at the University of Memphis, aims through his book The Language of Disenchantment: Protestant Literalism and Colonial Discourse in British India, to destabilize the myth of religious neutrality that fuels the illusion of a secular modernity. In this book, the British engagement with colonial India provides a robust case study for a more general inquiry into modernity, secularity, and "the roots of modern exceptionalism and disenchantment" (162).

Yelle's Language of Disenchantment is written almost completely in response to the effects that the Christian Reformation had on the attitudes, characteristics, and modes of conduct of modernity. The idea that the Reformation inspired the modernization and secularization of society was first developed by Max Weber in his book The Protestant Ethic and the Spirit of Capitalism. Through globalization, the distribution patterns of secularization described by Weber have influenced the modernization of world cultures, thus leading to what has been termed 'disenchantment'. Yelle-borrowing from Weber-takes 'disenchantment' to mean the following: "the decline of belief in miracles, mystery, and magic," (7) which results in the creation of modernity. It is this exportation of disenchantment, from Christianity to world cultures, that Yelle aims to discuss in this book-in particular, The Language of Disenchantment focuses on the British colonial endeavor in India, and the colonial effort to bring allegedly-secular Western modernity to India.

The notion of disenchantment is treated as an historical and linguistic event by Yelle-a treatment that through the book sometimes risks being read as a modification of historical data to suit a new history of modernity. 
However, by working with this particular definition of disenchantment, Yelle is able to make very specific claims about the ways in which Hindu culture under British colonial rule was affected by Protestant ethics disguised as secular modernity. In particular, Yelle focuses on a few definitive ways in which Reformation and post-Reformation values were upheld in British India. In chapter 2, "A Disease of Language," Yelle discusses the colonial classification of Hindu worship of multiple gods or images (murti) as idolatry. Here, he positions disenchantment as a primarily linguistic entity. In chapter 3, "One Step from Babel to Pentecost," the dismissal of Hindu ritual as inferior to textual authority is discussed. This, Yelle suggests, is an effect of the Protestant mandate of sola scriptura, and the insistence on a uniformed reading of scripture due on Protestant literalism and the Christian conviction in the universality God. Chapter 4, "Vain Repetitions," discusses the colonial criticism of Hindu ritual language, such as chants and mantras, as verbal idolatry and the anthropomorphication of God. This was a criticism previously leveled by the Protestants against the Catholics. In the final chapter of this book, "The Hindu Moses," Yelle discusses the colonial criticism of Hindu law codes, such as the Dharmasastras-an ancient Hindu text that draws no separation between ethic, cosmology, and ritual code. This lack of separation between law, religion, and ritual was viewed by the British colonizers as primitive and un-evolved, since modern society is meant to separate secular societal values from religious ones. This critique mirrored the Christian critique of Jewish ritual law as codified in the Hebrew Bible.
Each of Yelle's main chapters thoroughly and effectively analyzes the four aforementioned issues. A particular strength of Yelle's work here is his drawing of patterns: of the similarities between the colonial encounter of the British in India, and the historical polemics of Protestants against Catholics, Christians against Jews, and Jews against Gentiles. Furthermore, Yelle uses his arguments to expand on Weber's work on the Christian dimensions of disenchantment. In fact, Yelle goes further than Weber did by drawing attention to the value imposition on another culture through the colonial endeavor. In The Disenchantment of Language, Yelle is able to ambitiously engage with the history of colonialism in a way that is both unique and engaging-through his analyses, he is able to add a new and valuable theological dimension to the conversation about India's engagement with British colonial powers.

By exploring the idea of disenchantment through the particular case of British colonial interaction in India, Yelle has written a book that effectively contributes to the fields of India Studies, Postcolonial Studies, and HinduChristian Studies. Yelle is successfully able to debunk claims to the universality of Western reason as produced by Protestant, postReformation thought. Though focused on the colonial encounter in India, this book is ultimately about a broader issue regarding modernity: that the myth of disenchantment that is held so dear in modern societies, is one that must be questioned and challenged. Yelle concludes that by continuing to expose the origins of the myth of disenchantment-as he has done in this book-we are able to broaden our awareness about the impact of this mode of 
thinking and its pervasiveness in our quest for modernity.
Roselle M. Gonsalves

University of Calgary

\section{A Matter of Belief: Christian Conversion and Healing in North- East India. Vibha Joshi. New York: Berghahn Books, 2012, 298 pages.}

Do not let the title fool you into thinking that A Matter of Belief consists of theologically splitting hairs. This well-researched anthropological and archival study of contemporary practices of healing that draw from both traditional Naga-Angami and Christian spheres of influence should perhaps be titled a matter of practice, rather than belief. Joshi's work is the fruit of intermittent fieldwork since 1985 on traditional healers in an area that is often closed to researchers due to violent upheavals from internal rifts between Naga political groups seeking different forms of independence and external tensions with at first British, and later Indian governments. Her work utilizes interviews with informants, as well as historical records, including missionary letters, officer tour reports, and the work of her main interlocutor, J.H. Hutton, a civil servant turned anthropologist who wrote a definitive study of the Naga peoples in 1921. As not many people are versed in Naga history, Joshi begins with a concise primer of the complex relationships between religious worldviews (Angami animism and various forms of Christianity), politico-military entities and the current revival of Naga culture as a detailed backdrop before launching into her main argument that is of interest to scholars of global Christianities, South Asia, and global health.
The primary position of this book centers on a critique of anthropological assessments that blame Christianity for wiping out traditional animist religious forms (52) or that oversimplify Angami religion as "syncretic"(3). Instead, Joshi asserts a more fluid picture of religion, as explored at its intersection with healing practices. The author insightfully frames Angami Christian and non-Christian practices as "two broad alternating streams of discourse, one masking the other but at different times and in different guises" (3), rather than as a bifurcated either/or scenario. The Angami are statistically 90\% Christian (4), and have been significantly influenced by educational and medical missions beginning with Baptists, but also Catholics and various Revival denominations. What is missing, Joshi astutely notes, is an examination of the “agency of the 'transporter' and that of the recipient, and the criteria for selection - who selects, and what is being selected" (7) when it comes to understanding the formation of Naga Christian identity and practices. Joshi makes a compelling case that the lens of healing provides a particularly beneficial, multidimensional window into Angami understandings of self-selection of various Christian and animist elements as determined in each context. 